\title{
MAKANAN SATWIKA DAN PROFIL LIPID PADA BHAKTA SAI DENPASAR
}

\author{
Oleh: \\ Gede Ngurah Budiyasa \\ Laboratorium Patologi Klinik \\ Rumah Sakit Umum Daerah Wangaya, Denpasar \\ gn.budiyasa@gmail.com
}

\begin{abstract}
Sattvik food is a social phenomenon in food consumption. Sativik food almost qual to vegetarian food. The menu is popular among the Saa Baba devotees spiritual group. Sattvik food was listed in the Bhagawad Gita XVI1.8, are foods that exalts life, energy, strength, health, happiness andjoy, a sweet, soft, contains a lot of nutrients, and tastes good is favored by wise people (sattvik). Sattvik food associated with materials, obtaining, tools used, how to cook and eat them. Before consumption must be chanted Brahmaarpanam prayer (mantram). Sattvik food can maintain lipid profile remained normal at the age of forty years above.
\end{abstract}

\begin{abstract}
Abstrak
Makanan satwika adalah sebuah fenomena sosial dalam konsumsi makanan Makanan satwika hampir sama dengan makanan vegetarian. Menu ini populer di lingkungan kelompok spiritual Sai Baba. Makanan satwika termuat dalam Bhagawad Gita XVII.8, adalah makanan-makanan yang meninggikan hidup, tenaga, kekuatan, kesehatan, kebahagiaan dan suka cita, yang manis, yang lunak, banyak mengandung zat-zat makanan, dan rasanya enak adalah disukai oleh orang baik (satwika). Makanan satwika berhubungan dengan bahan, cara memperoleh, alat-alat yang dipakai, cara memasak dan mengonsumsinya. Sebelum dikonsumsi harus diucapkan doa (mantram) Brahmaarpanam. Makanan satwika dapat, menjaga profil lipid tetap normal pada usia empat puluh tahun ke atas.
\end{abstract}

Kata kunci: makanan satwika, bhakta Sai, profil lipid

\section{PENDAHULUAN}

\subsection{Latar Belakang Masalah}

Kemajuan industrialisasi yang menyebabkan pesatnya arus urbanisasi telah mengubah perilaku hidup (life style) dan pola makan masyarakat. Di samping gemar mengonsumsi fast food, berkurang pula masyarakat melaksanakan aktivitas sehari-hari dengan berjalan kaki. Mereka lebih cenderung memilih naik kendaraan pribadi. Dahulu masyarakat biasa memasak sendiri di rumah, tidak seperti sekarang yang lebih terbiasa makan di luar rumah (Suastika, 2007: 1).

Makanan cepat saji (fast food) merupakan makanan yang mengandung kalori tinggi, demikian juga kandungan lemaknya konsumsi makanan yang mengandung banyak gula dan lemak, selain meningkatkan asupan kalori yang akan ditumpuk dalam jaringan lemak tubuh ju- 
ga akan meningkatkan kadar trigliserida dan kolesterol (Winarta, 2007: 14-15).

Studi yang dilakukan oleh Devlin (2002: 1131) menunjukkan bahwa komposisi makanan saat ini terdiri atas $42 \%$ lemak, $12 \%$ protein, dan 46\% karbohidrat. Kalau diperinci, lemaknya terdiri atas 16\% lemak jenuh, 19\% tak jenuh tunggal, dan $7 \%$ tak jenuh ganda. Komposisi makanan zaman sekarang ini dalam jangka panjang sangat tidak baik untuk kesehatan. Kedepannya persentase lemak ini harus diturunkan menjadi $30 \%$ dengan komposisi $10 \%$ jenuh, $10 \%$ tak jenuh tunggal, dan $10 \%$ tak jenuh ganda.

Gaya hidup mewah, makanan lezat, minuman berkadar gula tinggi dan lemak telah menjadi bahan bakar yang menyulut epidemic global overweight dan obesitas. Secara global, terdapat satu miliar orang dengan berat badan lebih dan paling sedikit tiga ratus juta di antaranya dengan obesitas. Kini obesitas menjadi epidemi dan menjadi masalah karena menyimpan bom waktu untuk meledaknya sejumlah penyakit di kemudian hari. Semakin banyak timbunan lemak di rongga perut akan diikuti dengan tingginya kolesterol low density lipoprotein (LDL) dan kolesterol total. Di samping itu, juga diikuti dengan meningkatnya kadar trigliserida dan menurunnya kadar kolesterol high density lipoprotein (HDL). Peningkatan kadar ini disebut juga dengan dislipidemia (Suastika, 2007: 1-4).

Di tengah makin banyaknya warung dan restoran fast food dewasa ini, muncul fenomena sosial baru di dalam mengonsumsi makanan yang dikenal dengan diet satwika. Makanan satwika ini belum banyak dikenal oleh masyarakat, termasuk masyarakat Hindu di Bali. Diet satwika hanya populer khusus di lingkungan kelompok spiritual.

Makanan yang lebih dikenal luas oleh masyarakat, termasuk juga masyarakat internasional adalah menu vegetarian. Menu satwika ini hampir sama dengan makanan vegetarian. Makanan satwika dapat ditemukan dalam tuntunan makanan sehat pada kelompok spiritual Ananda Marga dan di Sai Study Group Indonesia atau SSGI (Ananda Marga, 1991: 28; Acarya, 2005: 2-8; Mahilawibag, 2011: 1- 8).

Makanan satwika tidak mengandung semua jenis bahan hewani (daging, unggas, telur, ikan, seafood), tapi masih dibolehkan mengonsumsi susu. Umumnya menu mereka mengandung bahan nabati yang cenderung rendah lemak, dan kolesterol (Aditya, 1999: 23; Amirta, 2007: 116; Candra, 2010: 1).

Menu vegetarian dikonsumsi pada umumnya untuk beberapa alasan, seperti keyakinan agama, spiritual, ahimsa, kesehatan, lingkungan, etika, kasih sayang, atau alasan finansial. Di kalangan masyarakat Hindu, makan daging sangat erat kaitannya dengan keyakinan, ahimsa, dan spiritualitas. Artinya, makan daging akan memengaruhi pikiran dan jiwa manusia (Suhardana, 2010: 25-27).

Banyak penyakit yang disebabkan oleh faktor makanan, seperti penyakit jantung, kanker, dan hipertensi. Ilmu pengetahuan semakin berkembang dan akhirnya diketahui bahwa makanan sebagai salah satu faktor penting terjadinya penyakit-penyakit yang mematikan. Dikatakan bahwa 60-70 \% penyakit tersebut sebagai akibat pola makan atau gaya hidup (Suryaatmaja, 2003: 26-46; Wardhana, 2010: 1).

Menjadi seorang vegetarian atau mengonsumsi makanan satwika adalah hal tidak mudah untuk dilakoni, diperlukan sadhana atau disiplin spiritual. Untuk mendalami makanan satwika, dapat dirumuskan permasalahannya seperti di bawah ini.

1 Mengapakah bhakta Sai mengonsumsi makanan satwika?

2 Bagaimanakah pola konsumsi makanan pada bhakta Sai?

3 Apakah makna makanan satwika dan implikasi mengonsumsinya terhadap profil lipid?

\subsection{Landasan Teori}

Masyarakat Denpasar, khususnya umat Hindu dan bhakta Sai; adalah masyarakat kota besar yang sudah berpikir maju di samping berwawasan luas dan terbuka. Mereka lebih memahami filsafat agama yang dianutnya. Akhir-akhir ini media turut memberikan pengaruh besar terhadap pengetahuan agama bagi umat Hindu, misalnya dharma wacana dapat diikuti lewat media televisi dan radio. Dalam hal makanan bagi yang sudah berumur, utamanya di atas empat puluh tahunan, telah semakin rasional dan arif di dalam memilih makanan yang dianggap cocok dan menyehatkan.

Rational choice theory oleh Patrick Baert (dalam Wirawan, 2013: 209-213) dipakai untuk menjelaskan perilaku politik dan sosial dengan mengasumsikan bahwa orang-orang bertindak 
secara rasional. Teori ini mengasumsikan intensionalitas. Sesuai dengan wacana Sai Baba mengenai makanan satwika, di antara banyak opsi dari berbagai jenis makanan, inilah yang paling rasional untuk dikonsumsi, khususnya oleh bhakta Sai.

\subsubsection{Teori Fungsionalisme Struktural}

Teori fungsionalisme strukturai menekankan kepada keteraturan (order) dan mengabaikan konflik serta perubahan-perubahan dalam masyarakat (Ritzer, 2002:21; Sunarto, 2004: 216). Teori ini sangat sesuai dengan kondisi sosial di dalam organisasi Sai Study Group Denpasar, yang anggotanya adalah bhakta Sai Baba yang berdomisili di sekitar Kota Denpasar. Dalam aturan organisasi, semua yang duduk dalam kepengurusan diharuskan melakoni vegetarian (mengonsumsi makanan satwika). Demikian pula ketaatan bhakta Sai karena mereka percaya akan nilai-nilai kebenaran universal yang diwacanakau oleh Bhagawan Sri Sathya Sai Baba.

\subsubsection{Teori Psikoanalisis}

David Mc Celland mengatakan bahwa perubahan sosial terjadi karena adanya pertumbuhan dan/atau perkembangan motif berprestasi dari individu atau masyarakat. Daya dorong bagi seseorang untuk meraih prestasi yang lebih baik daripada hari ini disebut dengan need for achievement (n-Ach). Dalam diri individu juga ada motif untuk berafiliasi (need for affiliation), yaitu ia ingin mendapat pengakuan atau diakui oleh kelompoknya (Sudarma, 2008: 95 - 96). Teori ini menjelaskan mengapa bhakta Sai termotivasi untuk mengonsumsi makanan vegetarian (satwika).

\subsubsection{Teori Medis Biosintesis Lipid dan Kolesterol}

Makanan yang dikonsumsi oleh manusia akan mengalami pencernaan di dalam sistem pencernaan, kemudian diserap oleh dinding usus, dan diedarkan oleh darah. Demikian halnya dengan lemak yang dikonsumsi. Teori biosintesis lipid dan kolesterol ini dipakai untuk menjelaskan dan lebih memahami biosintesis pada pengonsumsi makanan vegetarian (makanan satwika).

Setelah mengalami pencernaan di usus, lemak menjadi bentuknya yang paling kecil, yaitu gliserol, asam lemak bebas, dan monogliserida.
Dalam sel usus mereka dirakit lagi menjadi trigliserida dan bergabung dengan kolesterol serta protein (apoprotein) menjadi kilomikron (chylomicrons). Lemak yang diperlukan oleh jaringan tubuh dapat diambil dari chylomicrons yang beredar. Sisanya yang disebut sebagai chylomicrons remnants diserap oleh sel-sel hati dan kemudian diolah menjadi very low density lipoproteins (VLDL), low density lipoprotein (LDL). Kelebihan kolesterol dan fosfolipid dari sel diambil dan dibawa kembali ke sel hati, yang mengandung apoprotein dalam bentuk high density lipoprotein (HDL) menuju sel hati. Lemak nabati terdiri dari asam lemak rantai pendek dan sedang. Lemak ini tidak diangkut melalui saluran khusus, tapi melalui jalur yang sama dengan makanan lainnya dan langsung dimetabolisme, sehingga tidak menyebabkan kenaikan kadar lemak (Sizer, 2000: 140 -142; Campbell, 2006: 599 601; Tymoczko, 2010: 442 - 444).

\subsection{Metode Penelitian \\ 1.3.1. Lokasi Penelitian}

Penelitian dengan pendekatan kualitatif ini dilakukan pada suatu komunitas kelompok spiritual Sai Baba, dalam suatu organisasi yang disebut dengan Sai Study Group (SSG) Denpasar. Mereka adalah bhakta Sai yang berdomisili di wilayah Kota Denpasar. SSG Denpasar melakukan kegiatannya di Ashram Prashanti Widya Sabha (Sai Center), yang berlokasi di Banjar Tegeh Kori, Kelurahan Tonja, Denpasar Utara.

\subsubsection{Jenis dan Sumber Data}

Data penelitian ini merupakan data kualitatif dan kuantitatif. Sumber data terdiri atas sumber data primer dan data sekunder. Data primer diperoleh secara langsung dengan pengamatan, wawancara, studi dokumen di lapangan, dan pengukuran di laboratorium. Bhakta yang memenuhi syarat, yaitu mereka yang benarbenar vegetarian tanpa terputus dalam kurun waktu lebih dari enam bulan, diambil darahnya sebanyak tiga mililiter. Selanjutnya diperiksa profil lipidnya di laboratorium Patologi Klinik.

\section{PEMBAHASAN}

\subsection{Penyebab Bhakta Sai Denpasar Mengonsumsi Makanan Satwika}

Orang mulai menyadari bahwa daging dan lemak tidak baik untuk menjaga kesehatan tubuh 
manusia, terutama bagi yang sudah berumur. Kesalahan-kesalahan yang dilakukan sebelumnya mulai berbuah. Pola hidup yang tidak teratur mulai berakibat buruk terhadap kesehatan (Das, 2012: 142). Upaya mengubah pola hidup, terutama yang berkaitan dengan kebiasaan makanan tidaklah mudah. Proses transformasi akan terjadi terlebih dahulu pada diri seorang bhakta sampai mereka mengonsumsi makanan satwika. Menurut Bhagawan (Sai Study Group Indonesia, 2010: 134 -142), transformasi mempunyai orientasi yang mengarah pada semangat perubahan menuju hari esok yang lebih baik.

Ada faktor-faktor yang memengaruhi bhakta Sai untuk memutuskan dirinya menjadi vegetarian atau mengonsumsi makanan satwika. Faktor-faktor tersebut dikelompokkan menjadi dua, yaitu faktor internal dan eksternal.

\subsubsection{Faktor Internal}

Faktor-faktor internal terdiri atas faktor pilihan rasional, faktor panggilan jiwa, faktor psikologi, dan faktor kesehatan.

Pilihan rasional merupakan proses yang mendasari pembuatan keputusan setiap individu. Masyarakat Denpasar pada khususnya merupakan masyarakat yang sudah maju, baik secara pengetahuan maupun pendidikannya. Pada zaman post modern sekarang ini penguasaan teknologi informasi sudah lebih merata, khususnya pada masyarakat perkotaan.

Dikatakan oleh Susianto (2014: 7) bahwa kesehatan dan tanggung jawab terhadap keseimbangan lingkungan dan makhluk hidup merupakan alasan utama seseorang beralih menjadi vegetarian (vegan). Demikian halnya yang terjadi pada diri dari banyak bhakta Sai. Banyak kebiasaan baik yang dapat terbentuk pada diri seorang bhakta.

Faktor psikologis adalah daya dorong bagi seseorang, seperti bhakta Sai untuk berprestasi yang lebih baik daripada bhakta Sai lainnya. Berprestasi dalam hal ini adalah konsumsi makanan sesuai dengan yang diwacanakan oleh Bhagawan Sri Sathya Sai Baba. Bhalda Sai adalah orang yang berbakti dengan sepenuh hati dan menempatkan Bhagawan Sri Sathya Sai Baba sebagai Sad Guru.

Bhakta Sai memiliki banyak tujuan dikaitkan dengan konsumsi makanan satwika. Salah satu di antaranya adalah yang ada hubungannya dengan faktor kesehatan. Kesehatan memiliki nilai yang semakin mahal harganya saat ini.

\subsubsection{Faktor eksternal}

Penyebab eksternal terdiri dari faktor struktural, religi, kegiatan organisasi dan pendidikan Sai (Sathya Sai School). Dalam perjalanan sebagai seorang bhakta, dengan ketekunannya seva (pelayaanan) akhirnya terpiiih menjadi pengurus organisasi Sai Study Group. Dalam waktu yang tidak begitu lama sebagai pengurus, akhirnya mereka menjadi yang duduk dalam kepengurusan harus melakoni vegetarian (mengonsumsi makanan Satwika).

Agama merupakan suatu sistem yang terdiri atas kumpulan keyakinan, tata cara, ritual atau upacara keagamaan, praktik-praktik, dan doadoa untuk mengambil hati Tuhan dan membawa manusia lebih dekat dengan-Nya. Seseorang yang religius pasti orang yang suci dan penuh bakti. Mereka disebut sebagai bhakta dan pemuja yang rajin kepada Tuhan pilihannya (Aditya, 1996: 96). Saat ini umat Hindu yang kritis pemikirannya tidak puas hanya dengan berupacara keagamaan semata, tetapi berkeinginan memahami lebih jauh arti dan maknanya. Mereka terus mencari dan ingin memahaminya. Dalam hal ini lingkungan adat yang masih tradisional dianggap belum mampu memenuhi keinginannya.

Misi Sai adalah menumbuhkan, mengembangkan, serta menjalin persahabatan dan persaudaraan dengan dasar cinta kasih. Misi ini dibangun dengan budaya Sai, yaitu love all serve all (kasihi semua layani semua). Kasih disemai melalui pelayanan yang dilandasi oleh rasa bakti, jauh dari segala ego dan pamrih.

Pendidikan memegang peranan sangat penting dalam menentukan nasib suatu bangsa. Untuk menyelamatkan pemuda dan negara dari bencana penghancuran diri, jalan keluarnya adalah pendidikan dengan menanamkan kesungguhan dan spiritual baru (Paramita, 2002: 34). Menurut Bhagawan, pendidikan adalah semua yang bersangkutan dengan pengembangan karakter. Pendidikan dapat mengenalkan siswa dengan lima dasar nilai-nilai kemanusiaan, yaitu kebenaran, keadilan, kedamaian, cinta kasih, dan tanpa kekerasan (Mirpuri, 2005: 28) 


\subsection{Pola Konsumsi Makanan Pada Bhakta Sai Denpasar}

\subsubsection{Konsumsi Makanan Pada Bhakta Sai} Denpasar

Makanan yang dikonsumsi oleh bhakta Sai pada umumnya ada perbedaannya dengan apa yang dikonsumsi masyarakat. Menu makanan yang dikonsumsi oleh bhakta Sai disebut dengan makanan satwika.

Makanan satwika adalah makanan yang murni. Makanan ini identik dengan makanan yang sehat. Makanan satwika adalah makanan yang sesungguhnya dibutuhkan oleh tubuh. Di sisi lain makanan satwika sering kali dianggap hanya untuk orang-orang yang sudah meninggalkan keduniawian. Makanan satwika tersebut dianggap tidak mungkin diterapkan dalam kehidupan sehari-hari (Sai Study Group Indonesia, 2011 : 1- 3).

\subsubsection{Makanan satwika}

Menurut pustaka suci Hindu, makanan dibagi menjadi tiga, yaitu makanan satwika, rajasika, dan tamasika. Makanan satwika ini secara jelas termuat dalam Bhagawad Gita XVII Adhyaya XVII, sloka 8:

ayuhsattvabalarogya

sukhapritivivardhanah

rasyah snigdha,h sthira hrdya

ahdrah sattvikapriyah

Artinya:

Makanan-makanan yang meningkaikan kuaIitas hidup, tenaga, kekuatan, kesehatan, kebahagiaan dan suka cita, yang manis yang lunak, banyak mengandung zat-zat makanan dan rasa enak adalah yang disukai oleh orang baik (satwika).

Makanan satwika hampir sama dengan vegetarian. Dalam makanan satwika tidak dibolehkan semua daging, ikan, dan telur. Akan tetapi, susu yang di dalam makanan vegan (strict vegetarian) tidak dibolehkan, ternyata tergolong bahan makanan yang satwika. Di samping itu, buah-buahan, sayur-sayuran, biji-bijian, umbiumbian dan kacang-kacangan pada umumnya tergolong bahan yang satwika (Acarya, 2005: 4).

\subsubsection{Bahan Makanan Satwika}

Beberapa pustaka suci Hindu memuat makanan yang tergolong satwika. Sumber yang memuatnya adalah Bhagawad Gita, Maharaany
Upanishad, Ayurveda, dan banyak buku yang merupakan wacana-wacana orang suci, seperti Bhagawan Sri Sathya Sai Baba.

Wacana Bhagawan Sri Sathya Sai Baba ada yang dimuat dalam Amrta Yarshini (Curahan Air Keabadian). Di dalamnya disebutkan bahwa makanan satwika terdiri atas susu sapi, mentega susu, keju, mentega, dadih susu, dan lemak susu. Selain itu, juga buah yang manis, sayur-sayuran, buah kering, kacang-kacangan, gandum, beras, sorgum, gula merah, green gram, bengal gram, jahe, dan madu (Aditya, 1999: 23).

Dijelaskan Bhagawan dalam wacana lainnya (Satvic, 2007; 2 -103) bahwa buah-buahan, sayur-sayuran, umbi-umbian, akar-akaran yang tidak dimasak, segar, mentah, yang dimakan dalam jumlah mencukupi dan dipelihara tanpa bantuan pupuk dan bahan kimia lainnya adalah makanan satwika yang paling baik. Susu mentah segar dari sapi yang dipelihara dengan kasih sayang dan bijak adalah minuman yang sangat satwika.

\subsubsection{Cara Mengolah, Memasak Makanan Satwika}

Agar tergolong satwika, masakan tidak bisa dilepaskan dari cara memasaknya. Cara memasaknya harus mengikuti cara yang baik, benar, dan suci. Periuk dan alat-alat memasak lainnya harus murni, demikian pula proses memasaknya harus murni. Kemurnian tidak hanya berarti kebersihan fisik, tetapi juga cara perolehan peralatan dan bahan-bahan makanan itu. Selain itu, juga harus diperhatikan kemurnian proses memasak serta dipastikan pikiran dan perasaan orang yang memasak (Drucker, 2001: 69).

\subsubsection{Cara Menghidangkan Dan Mengon- sumsi Makanan Satwika}

Dalam pustaka suci Bhagawad Gita (Drucker, 2001: 70) disebutkan bahwa sebeium makan supaya didahului dengan berdoa dan seluruh makanan dipersembahkan kepada Tuhan agar dibersihkan dan disucikan. Doa sebelum makan ini bukan untuk kepentingan Tuhan, melainkan untuk kebaikan sendiri. Dengan memohon rahmat Tuhan, makanan akan tersucikan. Doa yang dapat diucapkan sebelum makan adalah diambilkan dari pustaka suci Bhagawad Gita (N.24 dan XV.14), sebagai berikut.

Brahmaarpanam, Brahma havir,

Brahmaagnau Brahmanaa hutam, 
Brahmaiva tena gantavyam,

Brahma karma samaadhinaaha.

Aham Vaishvaanaro bhutvaa,

Praaninaam dehamaashritaha,

Praanaapaana samaa yuktaha,

Pachaami annam chatur widham.

Doa atau mantra mempunyai vibrasi yang baik terhadap ciptaan Tuhan. Demikian juga pengaruhnya terhadap makanan. Mantra yang tertuju kepada Sang Pencipta juga akan sampai kepada segala sesuatu yang ada di muka bumi. Veda memasukkan kemahakuasaan Tuhan, yaitu Astaaisvarya.

Manfaat dan pengaruh mantra atau doa dapat dibuktikan secara nyata. Penelitian tersebut dilakukan terhadap air oleh ahli dari Jepang, yaitu Masaru Emoto. Da1am bukunya The Hidden Message diuraikan bahwa air bersifat bisa merekam pesan seperti pita magnetik atau compact disc. Temuan ilmuwan Jepang ini membuktikan khasiat doa (mantra) yang ditransfer melalui air memang nyata. Menurut hasil temuan Masaru Emoto tersebut, semua benda yang ada di dunia ini mempunyai gelombang (hado). Energi ini bisa berbentuk positif atau negatif dan bisa dipindahkan dari satu benda ke benda yang lain (Hamidin, 2012: 16 - 21).

\subsection{Makna Makanan Satwika Dan Implikasi Mengonsumsinya Terhadap Profil Lipid Bhakta Sai Denpasar}

\subsubsection{Makna Makanan Satwika}

Hasil penelitian ini dapat mengungkapkan beberapa makna makanan satwika. Makna-makna tersebut adalah makna pengendalian lidah dan pikiran, pengamalan ahimsa, peningkatan spiritual, makanan suci (prasadam), dan makna kesehatan.

Setiap alat indra manusia memiliki satu kegunaan khusus, tetapi lidah diberikan kemampuan ganda, yaitu kemampuan berbicara dan cita rasa. Bhagawad Gita mengingatkan agar orang berhati-hati di dalam menggunakan lidahnya. Di sana dipuji bagi bhakta yang mampu mengendalikan lidahnya dengan sempurna. Orang semacam itu akan segera memperoleh hati yang mantap, bersih, tabah, dan senantiasa merasakan kehadiran Tuhan.

Pengendalian lidah tidak saja terhadap jenis bahan makanan, akan tetapi juga kapan waktu- waktu mengonsumsinya. Orang yang makan tiga kali disebut sebagai orang sakit (rhogi), orang yang makan dua kali sebagai penikmat (bhogi), dan orang yang makan sekali sebagai yogi.

Tubuh merupakan tempat tinggal yang abadi bagi atma. Ahimsa menurut pengerkian Sri Chandrasekhararendra (dalam Suhardana, 2010: 4) adalah tanpa kekerasan, penghormatan terhadap kehidupan, tidak membunuh, dan tidak melukai. Dalam Bhagawad Gita (Mantra, 2000: 191) terdapat sloka 13 dari bab XII, yang menyatakan sebagai berikut. la, yang tidak mempunyai kebencian pada makhluk apa pun, yang ramah-tamah, dan mempunyai rasa kasih, bebas dari keakuan dan "aku punya", sama dalam kesakitan, kesenangan, dan sabar.

Menurut Bhagawan, spiritualitas adalah pengetahuan tentang alma. Atma adalah kasih, kebenaran, kedamaian, kebahagiaan, kegembiraan atau kenikmatan. Seseorang yang percaya bahwa dia adalah atma serta mencoba hidup dan berperilaku sedemikian rupa, yaitu dirinya yang berketuhanan, sesungguhnya adalah orang yang spiritual (Aditya, 2000: 97).

Hindu tidak mengenal istilah makanan halal atau haram. Di Bali dikenal dengan istilah sukla. Istilah makanan di dalam Hindu adalah makanan prasadam atau makanan suci. Sebelum menyantap makanan, orang harus berdoa dan mempersembahkan seluruh makanan kepada Tuhan. Hal ini dimaksudkan untuk membersihkan dan memurnikan makanan tersebut. Doa yang diucapkan akan menjadikan makanan itu sebagai makanan yang berkhasiat (prasadam). Doa akan menghilangkan semua kekurangan yang ada pada makanan dan pengaruh negatif pada saat proses pemasakan (Satvic, 2007: 32 36).

Makna kesehatan yang berhasil diungkapkan dalam penelitian ini terdiri atas sehat secara fisik (fisiologis), sehat mental (psikologis), dan sehat secara sosial. Makanan satwika yang dikonsumsi menimbulkan implikasi terhadap kesehatan bhakta Sai. Hal ini dirasakan oleh bhakta khususnya yang sudah melakoni sejak waktu yang lama.

\subsubsection{Pengaruh Makanan Sehari-Hari Terhadap Profil Lipid}

Kemudahan memperoleh makanan siap santap (fast food) juga memen kebiasaan makan masyarakat. Makanan siap santap mudah diper- 
Tabel 1. Gambaran Profil Lipid Masyarakat Denpasar, Umur 20 - 59 Tahun

\begin{tabular}{|c|c|c|c|c|c|}
\hline No. & $\begin{array}{c}\text { Kelompok umur } \\
\text { (tahun) }\end{array}$ & $\begin{array}{c}\text { Jumlah sampel } \\
\text { (orang) }\end{array}$ & $\begin{array}{c}\text { Kadar KT } \\
(\mathrm{mg} / \mathrm{dl})\end{array}$ & $\begin{array}{c}\text { Kadar TG } \\
(\mathrm{mg} / \mathrm{dl})\end{array}$ & $\begin{array}{c}\text { Kadar LDL } \\
(\mathrm{mg} / \mathrm{dl})\end{array}$ \\
\hline 1. & $20-29$ & 16 & 175 & 97 & 104 \\
\hline 2. & $30-39$ & 52 & 194 & 165 & 111 \\
\hline 3. & $40-49$ & 94 & 211 & 186 & 131 \\
\hline 4. & $50-59$ & 31 & 218 & 177 & 138 \\
\hline
\end{tabular}

oleh di mana-mana, terutama di kota-kota besar, seperti di pusat-pusat perbelanjaan (mall), pasar swalayan, dan sekolah. Pada umumnya makanan ini kaya energi, lemak, karbohidrat, dan garam, tetapi kurang mengandung vitamin A, vitamin C, riboflavin, asam folat, kalsium, dan serat (Almatsier, 2011: 334 - 335).

Pola makan modern (masa. kini) masyarakat, khususnya di Kota Denpasar mempunyai implikasi pada profil lipid. Profil lipid terdiri atas kadar kolesterol total, trigliserida, high density lipoprotein (HDL) dan low density lipoprotein (LDL).

Profil lipid diketahui dari hasil pemeriksaan laboratorium. Berikut adalah gambaran profil lipid, yang dibagi menjadi empat kelompok umur, yaitu 20 sampai dengan 29 tahun, 30 sampai dengan 39 tahun, 40 sampai dengan 49 tahun, dan 50 sampai dengan 59 tahun. Pengelompokan ini dimaksudkan untuk memperoleh gambaran kecenderungan mulai terjadinya dislipidemia pada masyarakat dewasa ini.

Secara keseluruhan dari sebanyak seratus sembilan puluh tiga orang yang berpartisipasi didapatkan gambaran seperti berikut ini. Pada kelompok umur 30 sampai dengan 39 tahun, jumlah spesimen untuk tiap-tiap kelompok umur hanya sedikit. Demikian pula kelompok 20 sampai dengan 29 tahun, bahkan lebih sedikit lagi. Setelah diambil rerata (mean) per kelompok umur, didapatkan gambaran profil lipid pada tabel 1 berikut.

Tabel 1 dapat lebih jelas menunjukkan kadar kolesterol total, trigliserida, dan LDL pada empat kelompok umur. Di sini sangat jelas ditunjukkan bahwa rerata kadar profil lipid pada kelompok 20 sampai dengan 29 tahun dan 30 sampai dengan 39 tahun umumnya masih dalam batas normal. Kadar pada dua kelompok di atasnya, yaitu 40 sampai dengan 49 tahun dan 50 sampai dengan 59 tahun berada pada kadar di atas normal atau sudah ditemukan dislipidemia.

\subsubsection{Metode Masa Kini Pencegahan Dislipidemia}

Saat ini di dunia dikenal ada banyak diet sehat. Salah satu yang terkenal adalah diet Mediterania. Diet Mediterania merupakan salah satu metode diet dengan asupan nutrisi yang terinspirasi dari pola makan tradisional masyarakat Italia Selatan, Yunani, dan Spanyol. Inti program diet ini adalah mengonsumsi sayuran, buah, dan minyak zaitun secara rutin. Diet ini dapat menurunkan dislipidemia dan risiko penyakit degeneratif, seperti penyakit jantung, diabetes tipe 2, obesitas (diakses 23 Juli 2015 dari www.cara menurunkan_berat__ badan9.com/2015/04/ mediterania-untuk.html).

Diet sehat lainnya dikenal dengan diet DASH. Kata DASH merupakan singkatan dari Dietary Approaches to Stop Hypertension. Di samping dapat menurunkan tekanan darah, diet ini juga dapat menurunkan kadar kolestrol darah. Diet sehat ini sangat fleksibel, tidak sulit untuk dilakoni. Makanan ini bisa dikatakan sebagai versi Amerika dari diet Mediterania. Diet DASH terdiri atas buah-buahan, sayur-sayuran, dan produk budi daya rendah lemak. (Sacks, M. F. 2001: 310; diakses 23 Juli 2015 dari www.dashdiet.org/ what is the dash diet.asp). Orang yang mengonsumsi diet DASH di samping mampu menurunkan tekanan darah penderita hipertensi juga dapat menurunkan kadar lipid dan kolesterol. Pada penelitian yang melibatkan 436 peserta dengan konsumsi selama delapan minggu, diperoleh penurunan kadar kolesterol total sebesar 13,7 mg/dl dan kadar LDL sebanyak 10,7 mg/dl (Obarzanek, 2001: 80 - 89). 
Tabel 2 Profil Lipid Bhakta Sai Denpasar yang Vegetarian (Satwika)

\begin{tabular}{|c|c|c|c|c|c|}
\hline No. & $\begin{array}{c}\text { Lama Satwika } \\
(\text { tahun })\end{array}$ & $\begin{array}{c}\text { Kadar KT } \\
(\mathrm{mg} / \mathrm{dl})\end{array}$ & $\begin{array}{c}\text { Kadar TG } \\
(\mathrm{mg} / \mathrm{dl})\end{array}$ & $\begin{array}{c}\text { Kadar HDL } \\
(\mathrm{mg} / \mathrm{dl})\end{array}$ & $\begin{array}{c}\text { Kadar LDL } \\
(\mathrm{mg} / \mathrm{dl})\end{array}$ \\
\hline 1. & $<2$ & 174 & 122 & 43,6 & 105 \\
\hline 2. & $2-4,9$ & 162 & 107 & 42,0 & 98 \\
\hline 3. & $5-9,9$ & 160 & 147 & 40,2 & 86 \\
\hline 4. & $>10$ & 159 & 125 & 41,8 & 93 \\
\hline
\end{tabular}

\subsubsection{Profil Lipid Pada Vegetarian/ Satwika}

Kadar normal: KT $(<200 \mathrm{mg} / \mathrm{dl}) ; \mathrm{TG}(<150$ $\mathrm{mg} / \mathrm{dl}$ ); HDL (laki-laki: $40 \mathrm{mg} / \mathrm{dl}$, wanita: 50 $\mathrm{mg} / \mathrm{dl}) ; \mathrm{LDL}(<130 \mathrm{mg} / \mathrm{dl})$

Pada penelitian ini, secara keseluruhan berhasil diperiksa sebanyak enam puluh tujuh pengonsumsi vegetarian/satwika. Hal ini terjadi karena untuk menemukan bhakta yang benarbenar vegetarian/satwika, yaitu bebas dari kandungan unsur hewani, seperti terasi dan telur masih sulit. Masyarakat Hindu, lebih-lebih yang tinggal di Bali masih sangat kuat memegang tradisi atau budaya. Artinya masyarakat sering terlibat dalam kegiatan adat, budaya, dan agama yang menggunakan unsur daging, telur, dan terasi.

\subsubsection{Asupan Diet Dan Apaya Pennrunan Kadar Lemak Darah}

Dalam dua dekade terakhir ini perhatian utama tertuju kepada faktor nutrisi untuk menjaga kadar lemak dan kolesterol darah. Asupan diet kaya kolesterol dan lemak jenuh mempunyai kontribusi besar dalam peningkatan prevalensi aterosklerosis, serangan jantung, atau infark miokard. Usaha secara terus-menerus dilakukan untuk menjaga profil lipid tetap normal. Usaha yang sangat efektif adalah dengan cara diet tinggi PUFA (lemak tak jenuh ganda), asam lemak omega-3 dan omega-6. Cara lainnya adalah mengonsumsi bahan nabati yang juga mengandung banyak steroUstenol, serat larut air, dan anti oksidan (Sharma, 2011: 11).

\subsubsection{Biosintesis Lipid Dan Kolesterol Pada Vegetarian/Satwika}

Kolesterol dalam tubuh ditentukan terutama oleh sintesis dan penjernihan (clearance). Jika kolesterol diet diturunkan dari 500 mg menjadi $250 \mathrm{mg}$ sehari dan lemak jenuh disusutkan separonya, maka serum kolesterol diharapkan berkurang sebanyak 15\% atau sekitar $30 \mathrm{mg} / \mathrm{dl}$. Makanan nondaging, selain zat gizinya yang diperlukan tubuh, juga mengandung banyak serat yang mempunyai peranan dalam penurunan absorpsi lipid dan kolesterol (Arisman, 2007: 85; Sharma, 2011: 6).

Konsumsi lemak yang dianjurkan adalah lemak dengan banyak kandungan poly unsaturated fatty acid (PUFA) dan mono unsaturated fatty acid (MUFA). Lemak jenis ini banyak didapatkan dari bahan nabati. Konsumsi lemak yang banyak mengandung PUFA atau asam lemak tak jenuh ganda dan MUFA tidak menghasilkan peningkatan kadar kolesterol dalam darah, bahkan sering menwnunkannya. Salah satu asam lemak yang termasuk PUFA, yaitu omega-3 (Sediaoetama, 2010: 98 - 99; Sharma, 2011: 6).

Jumlah atom karbon pada asa.m lemak berkisar antara 4 sampai dengan 24 atom karbon. Asam lemak rantai pendek (Ca - C6 ) dan rantai sedang (Cs - Cio) diabsorpsi langsung ke dalam vena porta dan dibawa ke hati untuk segera dioksidasi. Oleh karena itu, asam-asam lemak ini tidak memengaruhi kadar lemak darah (Almatsier, 2009: 66).

Bahan nabati seperti kedelai, banyak mengandung steroUstanol dan serat larut air. Serat larut air di dalam usus dapat mengikat kolesterol sehingga absorpsinya menjadi menurun. Bentuk molekul sterol dan stanol dari tumbuhan menyerupai kolesterol. Kejadian ini berakibat peningkatan dua sampai dengan tiga kali produksi very low density lipoprotein VLDL dan trias dislipidemia (Sharma, 2011: 11-13). 
Fitosterol merupakan sterol dari pangan nabati. Kemiripan moiekul fitosterol menyebabkan kompetisi penyerapannya di usus dengan kolesterol. Fitosterol tidak mempunyai efek negatif terhadap dinding pembuluh darah. Sumber utama fitosterol adalah biji-bijian dan minyak nabati. Fitosterol sudah dibuktikan secara klinis dapat menurunkan kolesterol total dan LDL sebanyak 10 sampai dengan 14\% (Anwar, 2009: 102 -105). Konsumsi sayuran secara teratur dalam jumlah cukup, bermanfaat menjaga kadar normal lemak darah. Saat sayuran di dalam usus akan menyerap asam empedu dan membuangnya bersama feses. Penurunan kadar asam empedu dalam usus akan merangsang tubuh untuk menarik lemak (kolesterol) dari dalam darah untuk diproses menjadi asam empedu di dalam hati. Sebagai akibatnya, konsentrasi lemak dalam darah tetap terjaga (Winarsi, 2007: 126).

\section{PENUTUP}

\subsection{Simpulan}

Makanan satwika diartikan sebagai makanan-makanan yang meningkatkan kualitas hidup, tenaga, kekuatan, kesehatan, kebahagiaan, dan suka cita. Makanan yang manis dan lunak, mengandung banyak zat makanan dan rasa enak merupakan makanan yang disukai oleh orang baik (saiwika).

Diet satwika sangat penting bagi kehidupan spiritual dan kesehatan. Upaya melakoni konsumsi makanan satwika sekaligus memurnikan pikiran dan menyehatkan badan dengan menyeimbangkan kecenderungan biologis, melepaskan racun-racun ( $a m a$ ) dengan menyediakan semua substansi nutrisi yang diperlukan. Makanan ini ditujukan untuk mengasah kepekaan diri, dijalankan dengan sadhana untuk menuju dhyana. Hal ini sesuai dengan tuntunan spiritual Bhagawan Sri Sathya Sai Baba.

Makanan satwika memberikan implikasi terhadap gambaran profil lipid. Bhakta yang sudah melakoni vegetarian atau mengonsumsi makanan satwika selama satu sampai dengan dua tahun, ditemukan profil lipid yang normal. Demikian juga yang melakoni sampai waktu yang lebih dari dua tahun, bahkan ada yang lebih dari sepuluh tahun. •

\section{DAFTAR PUSTAKA}

Acarya, A.A. 2005. Food For Thought The Vegetarian Philosophy. Third Edition. Jakarta.: Ananda Marga Publications.

Aditya, S.1999. Amrta Yarshini. (Curahan Air Keabadian). Wejangan Sri Sathya Sai Baba. Edisi Pertama. Surabaya: Paramita.

Almatsier. 2009. Pedoman Umum Gizi Seimbang. Jakarta: Direktorat Gizi Departemen Kesehatan.

Almatsier. 2011. Gizi Seimbang dalam Daur Kehidupan. Edisi Pertama. Jakarta: PT Gramedia.

Amirta, Y. 2007. Diet Sehat, Murah, dan Menyenangkan. Yogyakarta: Kreasi Wacana. Ananda Marga.

1991. Yoga - The Way Of Tantra. Fourth Editions. Ananda Marga Publications.

Anwar, F. 2009. Makan Tepat Badan Sehat. Edisi Pertama. Jakarta: Hikmah Sehat. Arisman, M.B. 2007. Gizi dalam Daur Kehidupan. Edisi Ketiga. Jakarta: EGC. Bahl, A., Bahl, B. S. 2007. Advanced Organic Chemistry. $21^{\text {st }}$ Edition. New Delhi: S. Chand \& Company Ltd.

Campbell dan Forrell. 2006. Biochemistry. Fifth Edition. Belmont: A Book.

Candra, K.A. 2010. "Makanan Suci untuk Spiritual". (diakses 30 Maret 2012). Tersedia dalam URL :http://www.mail-archive.com/hindudharma@itb.ac.idlmsg37860.htm1.

Das, S. 2012. Swami Sri Sathya Sai Baba, Sebuah Tafsir. Kuta: Koperasi Global Anand Krishna.

Devlin, T. M. 2002. Texbook of Biochemistry with Clinical Correlations. Fifth Edition. New York: Wiley - Liss.

Drucker, A. 2001. Intisari Bhagawad Gita. Wejangan Bhagawan Sri Sathya Sai Baba. Cetakan Ketiga. Surabaya: Paramita.

Hamidin, A.S. 2012. Keampuhan Terapi Air Putih. Edisi Pertama. Yogyakarta: MedPress. Mahila Wibag. 2011. Makanan Sehat untuk Keluarga dan Resep-Resepnya. Edisi Pertama. Jakarta: Sai Study Group Indonesia. 
Mantra, LB. 2000. Bhagawadgita. Denpasar.

Mirpuri, M. 2005. Our Contribution To The Nation. Jakarta: Sathya Sai Organization of Indonesia.

Obarzanek, E. et al. 2001. "Effects on Blood Lipids of A Blood Pressure Lowering Diet: the Dietary Approaches to Stop Hypertension (DASH) Trial". Am J Clin Nutr. 2001; 74 (1): 80-9.

Paramita, D. 2002. Sathya Darsan, Kegiatan di Ashram Sai Baba Edisi Pertama. Surabaya: Paramita

Ritzer, G. 2002. Sosiologi Ilmu Pengetahuan Berparadigma Ganda. Cetakan Ketiga. Jakarta: PT Raja Grafindo Persada.

Ritzer, G. dan Goddman, D.J. 2005. Teori Sosiologi Modern. Edisi Keenam. Jakarta: Prenada Media.

Sacks, M.F. et al. 2001. "Effects on Blood Pressure of Reduced Dietery Sodium and The Dietery Approaches To Stop Hypertension (DASH) Diet". The New England Journal of Medicine, Vol. 344, January 2001: pp. 3 -10.

Sai Study Group Indonesia. 2010. Transformasi Sai dari Visi Menuju Aksi. Edisi Pertama. Jakarta: Penerbit Sai Study Group Indonesia.

Sai Study Group Indonesia. 2011. Makanan Sehat untuk Keluarga dan Resep-Resepnya. Edisi pertama. Jakarta: Penerbit Sai Study Group Indonesia.

Satvic, G. T. 2007. Makanan Satwik dan Kesehatan. Surabaya: Paramita.

Sediaoetama, A.D. 2010. Ilmu Gizi untuk Mahasiswa dan Profesi. Edisi Kesembilan. Jakarta: Dian Rakyat.

Sharma, R. 2011. "Diet and Nutrition Therapy in Dyslipidemia Management". In: Karapetropie, M. and Aeimovie, Z., editors. Dyslipidemia: Causes, Diagnosis and Treatment. Novapublishers. P. 1 - 34.

Sizer, F.S. dan Whitney, E.N. 2000. Nutrition Concepts and Controversies. Eighth Edition. Stamford: Wadsworth.

Suastika, K. 2007. "Lingkar Pinggang, Barometer Kesehatan Anda". Makalah 25 Tahun Pmdia Denpasar Wujudkan Hidup Sehat Bahagia. Denpasar: Prodia.

Sudarma, N. 2008. Sosiologi Kesehatan. Edisi Pertama. Jakarta: Salemba Medika. Suhardana, K. 2010. Ahimsa dan Vegetarian Jalan Menuju Kasih Sayang. Surabaya: Paramita.

Sunarto, K. 2004. Pengantar Sosiologi. Edisi Revisi. Jakarta: Lembaga Penerbit Fakultas Ekonomi Universitas Indonesia.

Suryaatmaja, M. 2012. "Pemeriksaan Trigliserida Tanpa Puasa”. Summit, Lipid Update, Vol. 7, 2012: hal. 1. Jakarta: Summit.

Susianto. 2014. Yegan Itu Mudah. Jakarta: Mizan Publika.

Tymoczko, J. L. 2010. Biochemistry A Short Course. First Edition. New York: W. H. Freeman and Company.

Winarsi, H. 2007. Antioksi dan Alami dan Radikal Bebas. Edisi Kelima. Yogyakarta: Penerbit Kanisius.

Winarta, H. 2007. "Menuruxikan Berat Badan dengan Cara Sehat". Makalah 25 Tahun Prodia Denpasar Wujudkan Hidup Sehat Bahagia. Denpasar: Prodia.

Wirawan, I. B. 2013. Teori-Teori Sosial dalam Tiga Paradi,gma. Edisi Pertama. Jakarta: Kencana Prenadamedia Group.

www.caramenurunkanberatbadan9.com/2015/04/contoh-menu-diet mediterania-untuk.html 